\title{
Spotlights; Research Samplings; Literature, Politics, Photography and Athletics
}

\author{
Nancy L. Segal \\ Department of Psychology, California State University, Fullerton, California, USA
}

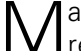
jor reared apart twin studies and the principal investigators behind them are presented. Personal tributes to two early researchers are provided by their colleagues and associates. Next, current twin studies and discussions of posttraumatic stress, synaesthesia, vanishing twins and bioethical issues are summarized. Human interest stories include twins in literature, politics, photography and athletics.
\end{abstract}

\section{Spotlights}

Reared Apart Twin Researchers

There are seven formal reared apart twin studies, past and present. We may well see new investigations in the future, due to increasing numbers of national twin registries (Boomsma, 1998; Busjahn, 2002) and improved methods for tracking adopted away relatives (e.g., reunion registries, Internet searches). I also anticipate a rise in separated twins from western nations - not only for the reasons mentioned above, but also as a byproduct of advances in assisted reproductive technologies (ART). Physicians cannot guarantee successful singleton pregnancies via artificial procedures, so a common option has been to implant multiple embryos. This practice has produced increased numbers of twins, triplets, quadruplets and more. An unfortunate consequence has been separation of multiple birth siblings by some families lacking resources to raise them.

I was associated with the Minnesota Study of Twins Reared Apart (MISTRA) between 1982 and 1991. The study originated with the famous Jim twins (Jim Lewis and Jim Springer) of Ohio, who first met in February, 1979 at age 39. The Jim twins' meeting affected not just their own lives and those of their families, but ultimately the course of twin research, the nature of psychological inquiry and the progress of medical investigation. It also fashioned the careers of many professors and students who became enchanted by the developmental stories only reared apart twins could tell. Had the Jim twins never met, many seminal (and now familiar), papers, chapters and presentations would not have been written, studied and debated.

When this article is in print, it will have been 24 years since the Jim twins met. That is nearly a silver anniversary. I have now been away from the Minnesota study for slightly longer than I was present. For this and other reasons it seems appropriate to recall the wonderful reared apart twin work that set the stage for current efforts and will surely affect those that follow. Rereading sections from original studies has been inspiring, informative and fun. I expect some Twin Research readers may be surprised, as I was, to discover new things about each investigation.

Below are brief summaries of each project's backgrounds, and the names and photographs of the principal investigators. Space considerations precluded more detailed treatments, but the contributions of countless collaborators and assistants are clearly acknowledged. There are, in addition, several case reports of reared apart twins in the medical and psychological literature that are not reviewed here; I may discuss these papers in a future column.

\section{Horatio H. Newman, Frank N. Freeman and $K . J$. Holzinger: The Big Three}

The first systematically conducted study of separated twins, Twins: $A$ Study of Heredity and Environment (1937), took place at the University of Chicago. It was undertaken by a truly multidisciplinary trio: a biologist (Newman), a psychologist (Freeman) and a statistician (Holzinger). Their original aim was to compare psychological similarities of 50 monozygotic (MZ) twin pairs and 50 dizygotic (DZ) twin pairs raised together. The idea of adding separated twins to the project occurred later when " ... it became obvious that this material alone [twins reared together] gave only an incomplete picture of the roles of heredity and environment and that it

Address for Correspondence: Nancy L. Segal, Department of Psychology, California State University, Fullerton CA 92834 USA.Email: nsegal@fullerton.edu 


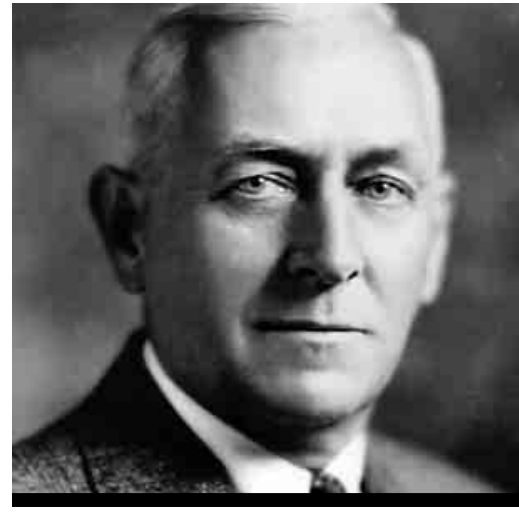

Figure 1

Horatio H. Newman

(courtesy of the University of Chicago,

Regenstein Library Archives).

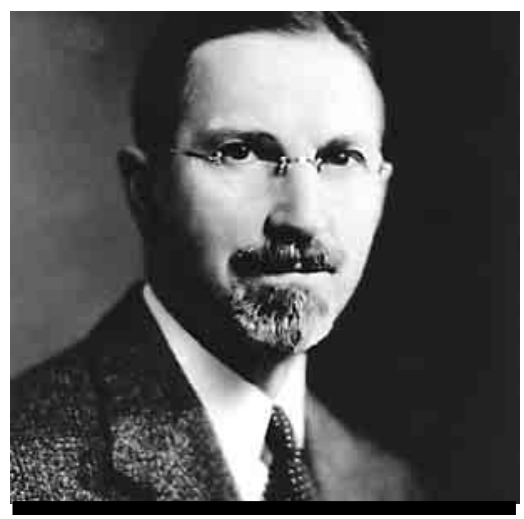

Figure 2

Frank N. Freeman (courtesy of the University of Chicago, Regenstein Library Archives).

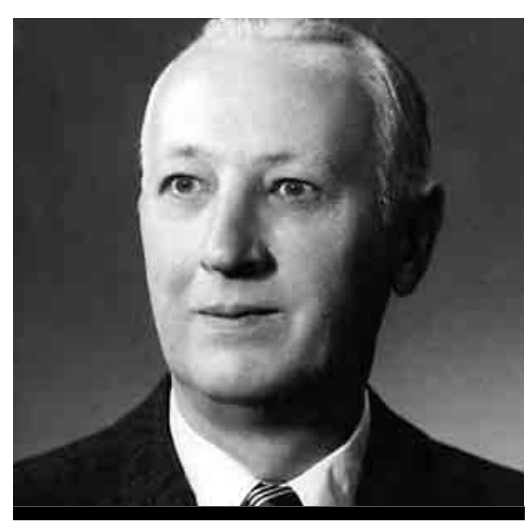

Figure 3

Karl J. Holzinger (courtesy of Dr. Holzinger's daughter).

badly needed to be supplemented by a study of identical twins reared apart" (p. 132). The aim was to find four or five such pairs.

Newman prepared several short articles for the purpose of recruiting separated twins. The research team was surprised and overwhelmed by the volume of responses, although not all replies yielded usable sets. In fact, most letters came from twins and "proud mothers of twins" (p. 132) eager to describe within-pair similarities and differences, and to seek answers to persistent problems. The most commonly asked questions concerned sterility or mental handicap in one co-twin. The team also received replies from many "non-identical twins reared apart, even twins of opposite sex" - unfortunately, these cases were excluded from the study.

Newman et al.'s final sample included 19 reared apart MZ twin sets. It was small in size, but nearly four times as large as anticipated. This was explained by the enormous publicity surrounding the first set ("through no fault of ours," p. 132), which led to additional contacts and cases. The descriptive material and accompanying photographs in this volume are still delightful to peruse.

I visited Holzinger's daughter at her home in Arizona sometime during the 1980s. She talked at length about her father and graciously provided me with a photograph and a newspaper clipping. The name and date of the newspaper were not noted, although given the subject, the date was most likely the late 1930 s or early 1940 s. The article noted that awards were won by two members of the research team: Newman and Holzinger were honored for their contributions by the American Educational Research Association; it is curious that Freeman did not share that award.

The comprehensive volume, first copyrighted in 1937, was renewed in 1965 by Newman's daughter, Marie and reissued in 1982 by Midway Reprints, a division of the University of Chicago Press. Midway's mission, etched on the book cover, is to "keep in print titles for which there is a steady but small demand". I stumbled upon my copy at a discount bookstore, either in Chicago or in Minneapolis. A nice feature of this edition is a fold-out chart with IQ, personality, handedness and dermatoglyphic data for each pair.

I contacted archivists at the University of Chicago's library for interesting materials about the study and the investigators. I recently received a note saying that the only relevant material was a 1928 reprint of a statistics article authored by Holzinger. Meanwhile, I explored the library's web site and came upon the following item, albeit not related to twin research:
The biology club [an informal gather- ing] also served as a source of support for Darrow in 1925 during the famous 'Monkey Trial' in Dayton, Tennessee. Backing Darrow's successful defense of John Scopes and evolutionary theory were expert witness statements pre- pared by three friends on the University faculty: zoologist Horatio H. Newman, educator Charles H. Judd, and anthropologist Fay-Cooper Cole (University of Chicago Exhib- ition Catalogues, 2002, online).

\section{James Shields: On the BBC}

Shields's 1962 study, Monozygotic Twins: Brought Up Apart and Together, is a classic among researchers investigating twins. It is astonishing, but true, that Shields investigated nearly all the pairs on his own. Most twins did visit the Maudsley Hospital, in London, but when this was not possible, he traveled to their homes or arranged for colleagues to do so. "In view of the scarcity of twins brought up apart and their great value as research material it was thought that the plan of the investigation should be sufficiently flexible..." (p. 22). Shields's volume is another wonderful blend of quantitative analysis and biographical detail.

Dr. Irving I. Gottesman worked closely with James Shields for many years. I asked him to prepare a brief tribute to his friend and colleague. It appeared on my computer screen

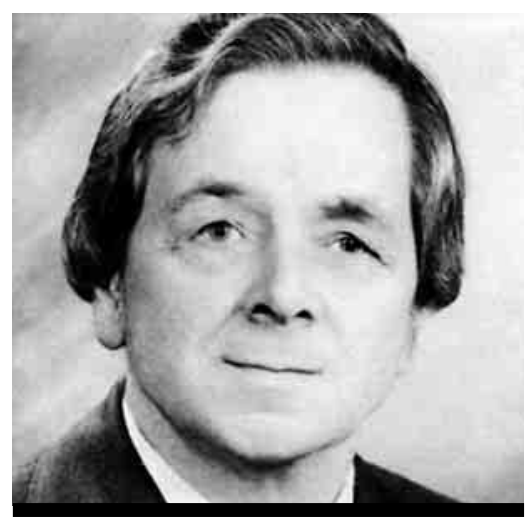

Figure 4

James ("Jerry") Shields

(courtesy of Dr. Irving I. Gottesman). 
less than 24 hours later - a tribute in itself:

After Newman, Freeman, and Holzinger published their systematic findings on 19 MZA pairs in 1937 , only sporadic case studies of such rare birds appeared until James (Jerry) Shields's remarkable series of 44 MZA pairs (together with 44MZT, 11DZA, and 17 DZT) was published in 1962. The magnum opus is all the more remarkable as it was accomplished despite two traumatic life events that would have dissuaded ordinary humans from a career in behavioral science. Born and reared in Scotland, his education at Merton College, Oxford University, was interrupted by the War in 1939; he was captured in France where he had been sent as a gunner in the Royal Artillery and spent the next five years as a POW in a German Stalag. After demobilization, he took training as a psychiatric social worker at the London School of Economics, and landed a job with Eliot Slater at the Maudsley Hospital. He was given a position as field worker to help Slater complete his study of 297 psychiatrically hospitalized twins that had begun in 1935. Shields co-authored the resulting 1953 monograph (Slater \& Shields, 1953).

Encouraged by Slater, Shields began his own study of MZA twins in early 1954 after some 5000 twins responded to a questionnaire in the Radio Times in connection with a broadcast on the BBC. Half-way through his work, in October, 1954, he was struck by poliomyelitis and was ill for two years including a life-threatening bout in an "iron lung." He resumed the work from his wheel chair in 1956, personally interviewing 74 of the twins altogether (including 28 sets).

I was paired with Shields by Slater in 1962 to carry out our study of 16 years of consecutive admissions to the Maudsley-Bethlem Royal Hospitals. This work continued after his untimely death in 1978, at age 60. His achievements as a twin researcher were recognized by a prized Honorary Doctor of Medicine degree from the University of Zurich in 1975." (Gottesman, personal communication to Nancy L. Segal, October 25, 2002).

\section{Niels Juel-Nielsen: Denmark's Reared Apart Population}

It is difficult to imagine a study whose unique participants come close to being the entire population of such individuals in the nation - but Juel-Nielsen's (1965) Danish sample is rare. The

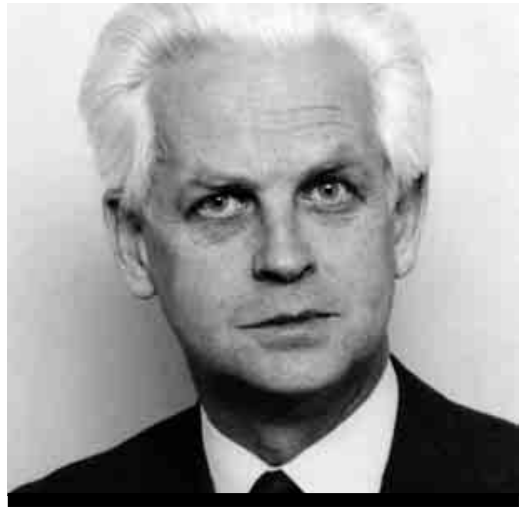

Figure 5

Niels Juel-Nielsen

(courtesy of Dr. Thomas J. Bouchard, Jr.).

volume, Individual and Environment: Monozygotic Twins Reared Apart, reported psychological, medical and life history findings for $12 \mathrm{MZA}$ twin pairs, 9 female and 3 male. Eight pairs were born between 1870 and 1910 and 4 were born between 1912 and 1934. The first 8 pairs were identified from the twin registry of the Institute of Human Genetics; the last four were found from among seven pairs that came to Juel-Nielsen's attention by chance. One twin in two sets could not be found, and co-twins in a third set had discordant blood-types, leaving 4 separated pairs that fulfilled the selection criteria. I had always assumed that the 12 sets were the population, as have many colleagues, but a closer reading of the introductory material indicates otherwise.

Juel-Nielsen gave considerable thought to the representativeness of his sample and to the final four pairs that were not part of the registry. First, the identification of an MZ male set born in 1907 , but registered in 1962, confirmed the fact that not all MZA twin pairs in Denmark were recruited for the study. Second (with respect to the final four), if they had volunteered for study, possible self-selection for similarity could have affected the findings. However, only one of the four pairs specifically volunteered for research and important differences between them were noted during the investigation. Juel-Nielsen's decision to include the 4 pairs was made, in part, to bring greater age diversity to the final sample; the 8 registry twin pairs were older than those found later. However, as he notes, most cases were gathered by systematic means.

Gudrun Hauge, secretary in the twin registry for 50 years, graciously provided the following tribute to Professor Juel-Nielsen. I am grateful to my friend and colleague, Dr. Kaare Christensen, at the University of Odense and Danish Twin Registry, for forwarding my request to her:

Niels Juel-Nielsen was born on 24 March 1920, in Denmark. He graduated in 1948 from the University of Copenhagen and the following year received the university's gold medal for a study on obesity in children. He specialized in psychiatry at the psychiatric hospital in Aarhus as a pupil of the late Professor Erik Strömgren under whose influence he started on his epidemiological-genetic line of research.

Juel-Nielsen's interests focused on the study of twins reared apart. This work was continued under his appointment at The Institute for Human Genetics at the University of Copenhagen, between 1952 and 1956. Here he made contacts with the Danish Twin Register (Mogens Hauge and Bent Harvald). His studies resulted in the 1965 volume, Individual and Environment: A PsychiatricPsychological Investigation of Monozygotic Twins Reared Apart. This study attracted considerable international interest, resulting in a revision and republication of his work in New York, in 1980 , by the International Universities Press, Inc.

In 1959, with Erik Strömgren, JuelNielsen established a psychiatricdemographic unit at Aarhus University. From 1970, he held the chair in psychiatry at Odense University. Under his professorship he continued his twin studies, in addition to studies on the causes of suicide. On several occasions he served as an expert consultant in suicide for WHO. In 1985, he became president of the XXI Congress of Scandinavian Psychiatrists, in Odense.

In his science, as a leader and as a physician, Juel-Nielsen was characterized by his gentle, quiet and modest behavior. As such, he succeeded in planning and realizing even very large projects. He was among the most outstanding personalities in Danish psychiatry and developed an extensive international network. Niels JuelNielsen passed away on 26 November 1986 from a coronary. 
In April, 2002, I visited Odense, the university town where Juel-Nielsen conducted his research and the venue for the 2004 International Twin Congress. It is always exciting to return to the source of studies that have profoundly affected the nature and progress of twin research.

\section{Thomas J. Bouchard, Jr: Minnesota Twins}

The Minnesota Study of Twins Reared Apart (MISTRA) began with the reunion of the Jim twins in February,

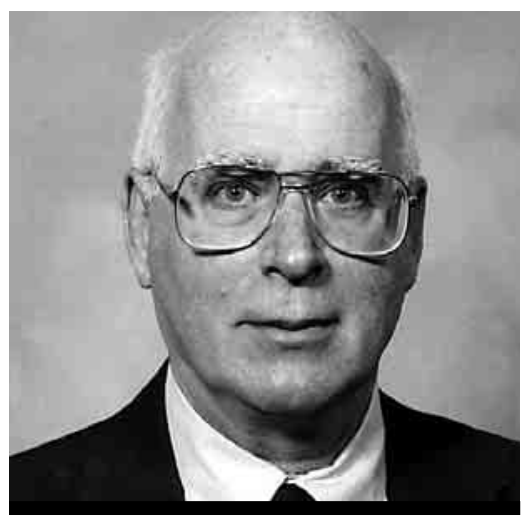

Figure 6

Thomas J. Bouchard, Jr.

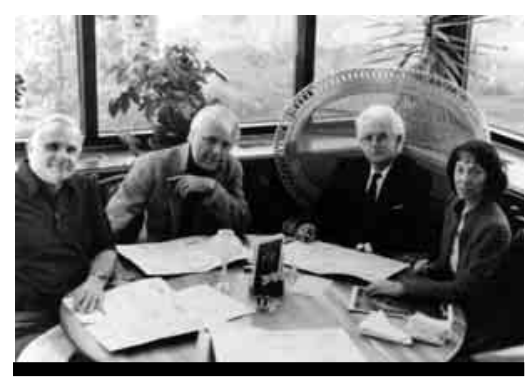

Figure 7

( $L$ to R) Leonard Heston, David T. Lykken, Niels Juel-Nielsen and Elke D. Eckert, during JuelNielsen's visit to the University of Minnesota in the early 1980s (courtesy of Dr. Thomas J. Bouchard, Jr.).

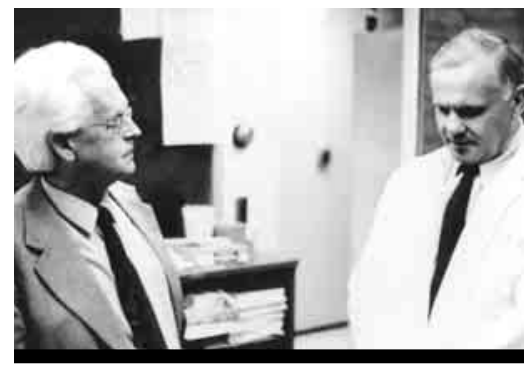

Figure 8

Niels Juel-Nielsen (L) and Leonard Heston during Juel-Nielsen's visit to the University of Minnesota in the early 1980s (courtesy of Dr. Thomas J. Bouchard, Jr.).
1979, as indicated above. One month later, Dr. Thomas J. Bouchard, Jr. invited the pair to the University of Minnesota to complete a comprehensive medical and psychological assessment. The twins' striking similarities (e.g., vacation spot, headache syndrome, weight gain) drew enormous media attention, attracting additional separated sets and, ultimately, launching the MISTRA. The decision to continue the study longterm was made only after 15 separated sets had been assessed. This project drew sustained interest from colleagues, the general public and, of course, the media. At present, 134 pairs have completed the comprehensive psychological and medical test battery, 80 of whom are MZ.

Numerous papers and presentations have resulted from this work and more will appear in the future. The wellknown IQ publication in Science (Bouchard, Lykken, McGue, Segal, \& Tellegen, 1990) reported an MZA intraclass correlation of $.69(+.07)$ for 48 separated sets, and an average weighted MZA intraclass correlation (based on three different tests) of .75. This paper probably attracted more attention than any other report from the project. However, the study was groundbreaking in other ways. The MISTRA was the first to publish personality findings using four twin types: MZAs, MZTs, DZAs and DZTs (Tellegen, Lykken, Bouchard, Wilcox, Segal, \& Rich, 1988). A surprising finding, replicated many times since, was that personality similarity is approximately the same in MZA and MZT twins, challenging conventional wisdom that shared environments explain shared personality traits in family members. A number of papers report findings on behaviors never previously studied in reared apart twins, such as brain waves, cardiac characteristics, dental and periodontal measures and psychomotor skills (see Segal, 2002).

The MISTRA was also the first study of reunited twins to include DZ twin pairs, both same-sex and oppositesex. This represented a significant advance over the three previous studies. Newman et al., in their quest to find only MZA pairs, may have systematically excluded more phenotypically dissimilar MZ sets, a possibility of which they were aware. The MISTRA was also among the first to arrange cotwin testing by independent examiners, wherever possible. This was a crucial procedure, especially with respect to IQ testing, a source of bitter controversy. However, intraclass correlations for twins from the Minnesota study do not differ from those reported by earlier investigators who did not always follow that practice (Bouchard et al., 1990). This demonstrates that when administration and scoring rules are well developed and closely followed, the use of same vs. different testers may not be an issue - except for critics (also see Segal \& Russell, 1991). It may be wise to employ separate testers for that reason alone.

\section{Nancy L. Pedersen: Generations of Swedish Twins}

The Karolinska Institutet maintains the famous Swedish Twin Registry, first established in 1959 (Pedersen, Lichtenstein, \& Svdeberg, 2002). Three cohorts are represented: twin pairs born between 1886 and 1925 , twin pairs born between 1926 and 1958 and twin pairs born between 1959 and 1990. Various life history data have been/are gathered periodically from the three cohorts via mailed questionnaires.

SATSA, the Swedish Adoption/Twin Study of Aging, represents a component of the larger data base. It includes twins separated at age 11 years, or younger, as well as a matched sample of twins reared together, allowing meaningful comparisons (Kendler, Thornton, \& Pedersen, 2000). SATSA began by sending questionnaires to these twins - information was obtained for rearing events, adult

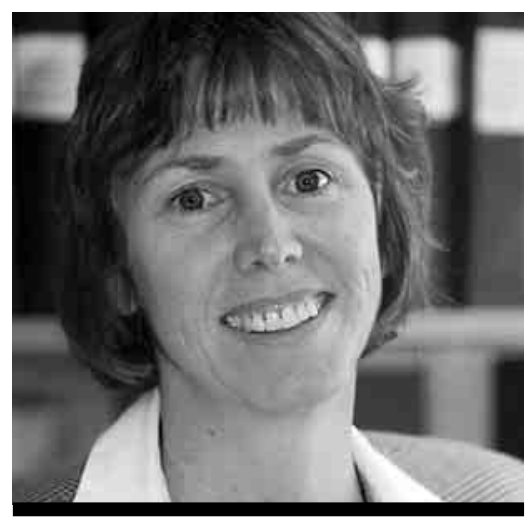

Figure 9

Nancy L. Pedersen. 
circumstances, work environment, health status, health-related behaviors, attitudes and personality. Additional mailings are sent every few years.

I will always recall SATSA as being the first study to publish IQ findings on DZ twins reared apart (Pedersen, McClearn, Plomin, \& Friberg (1985). (Shields reported data on DZA twins' intellectual similarities, but scores were available for only seven pairs; $r_{i}=.51$, for the combined Dominoes and Mill Hill.) Participants included 34 DZA pairs, 19 separated during the first year of life and 14 separated between ages 1 and 10 years. Tests included a 2-hour cognitive battery comprised of measures chosen to yield major factors similar to those in the Hawaii Family Study and Colorado Adoption Project (i.e., visual memory, spatial ability, verbal ability and perceptual speed). The median test correlation was .28; the general cognitive ability correlation (first principal component) was .52. Interestingly, twins separated earlier were more alike than those separated later.

Subsequent reports presented mental ability analyses using $\mathrm{MZ}$ and $\mathrm{DZ}$ pairs reared apart and together. Heritability for general cognitive skill later in life (using participants whose mean age was 64.1 years, $S D=7.5$ ) was estimated to be .80 , based on two assessments conducted three years apart (Plomin, Pedersen, Lichtenstein \& McClearn, 1994). A later analysis using reared together $\mathrm{MZ}$ and $\mathrm{DZ}$ twins, age 80 years or older, yielded a heritability estimate of .62 (McClearn, Johansson, Berg, Pedersen, Ahern, Petrill, \& Plomin,1997). These studies show that genetic influence on cognition remains significant across the life span, and that environmental effects consist mostly of experiential influences unique to individuals.

Space limitations preclude a full review of the numerous projects made possible by successive generations of Swedish twins. The riches yielded by the various components of the registry are well summarized in Sorensen (2002), Lichtenstein, De Faire, Floderus, Svartengren, Svedberg, \& Pedersen (2002) and Pedersen, Lichtenstein, and Svedberg (2002).

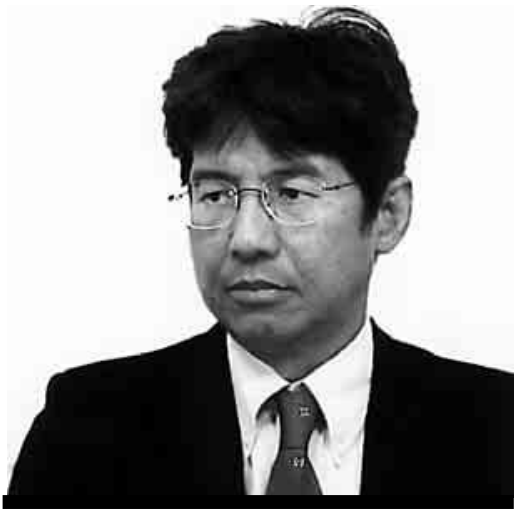

Figure 10

Kazuo Hayakawa.

\section{Kazuo Hayakawa: \\ End of a Tradition, Start of a Study}

Attitudes toward twins vary across and within cultures (Stewart, 2000). Twins are celebrated among the Yoruba of Western Nigeria (Olaleye-Oruene, 2002), but were disfavored in Japan during the 19th century and earlier (Veith, 1960). For example, the birth of twins to noble families was not revealed and the second twin was given away. Individuals present at the birth did not reveal the truth under threat of death. When male twins were separated, one was often raised by a courtier; however, if his co-twin died he was returned to his original family to take his brother's place. Thus, these mothers of twins did not feel the stress and stigma of multiple birth experienced by their lower class counterparts.

Attitudes and practices surrounding twinning in Japan have changed in recent times - in fact, in 1968 Japan became one of the first countries to organize support groups for mothers of twins (Bryan, 1992). Many will remember the 1992 meeting of the International Society for Twin Studies (ISTS) held in Tokyo, and the wonderful home visit with mothers of young pairs.

Personal correspondence to me from Professor Kazuo Hayakawa (25 October 2002), at the School of Health, at Osaka University, in Osaka, Japan shows that former twinning attitudes have left a valuable data source: "Since Japan had the long tradition to rear twins apart until recently, it is not difficult for Japanese researchers to obtain twin subjects reared apart". His current twin registry, described in
Twin Research, (Hayakawa, Shimizu, Kato, Onoi, \& Kobayashi, 2002) includes 12,000 twin pairs born between 1900 and 1935; 10\% of the twins or 1,200 pairs are MZ twins separated in early childhood.

Dr. Hayakawa began formal identification of twins reared apart and together in 1981. A sample of $\mathrm{MZ}$ male twins was organized according to age at separation: $0-5$ years: 15 pairs; 6-10 years: 0 pairs; $11-15$ years: 39 pairs; $16-20$ years: 45 years; 26 and over: 36 pairs. Zygosity was assessed by twins' responses to key questions from a standard physical resemblance questionnaire. These twins were part of the Kinki University Adult Twin Registry, which has been renamed the Osaka University Aged Twin Registry (OUATR). The focus is on aging and lifestyle contributions to psychological and physical development.

Early analyses were conducted to determine the extent to which shared environmental effects (as indexed by age at separation) might be associated with various health and lifestyle variables. In a number of measures, twins separated relatively early ( $0-5$ years) were less alike than those separated relatively late (26 years and beyond). For example, intrapair concordance increased from $50 \%$ to $78 \%$ for blood pressure, and from $59 \%$ to $87 \%$ for occupational choice. Of course, the findings require cautious interpretation, given the modest numbers of twins in each cell.

A subsequent, international study of body mass index (BMI) included 10 pairs of Japanese reared apart twins (Allison et al., 1996.) The BMI intraclass correlation was .73 for this group and .79 for all 53 separated twin pairs. Understanding differences in heritability for obesity between Japanese and Caucasian twins will be assisted by twins in the updated registry.

Recent twin analyses have been conducted on 100 health indices including serum lipid concentrations and physical measures (Hayakawa \& Sogi, 2000). Future studies promise to cover a wider range of fascinating behavioral domains. Plans are in place to compare food preferences in $M Z$ twins reared apart. Another project will assess behavioral differences in identical twins living separately, one in Japan 
and the other in the United States. International collaborations are welcomed by the research team.

\section{Jakko Kaprio and Markuu Koskenvuo: Finn Twins}

The original Finnish Twin Registry was established in 1974 (Kaprio, Koskenvuo \& Rose, 1990; Kaprio $\&$ Koskenvuo, 2002). It includes a cohort of like-sex twins born before 1958 with both twins alive in 1967. A data base for a second cohort was compiled in 1986 and includes all multiples born between 1958 and 1986. Within the larger registry, a subsample of reared apart twins was identified for specific analyses. Both separated co-twins in 165 pairs responded to questionnaires distributed in 1975 and 1979. In 1996, opposite-sex twins born between 1938 and 1949 were identified.

Early comparison of similarity in neuroticism between MZA twin volunteers and MZA registry twins

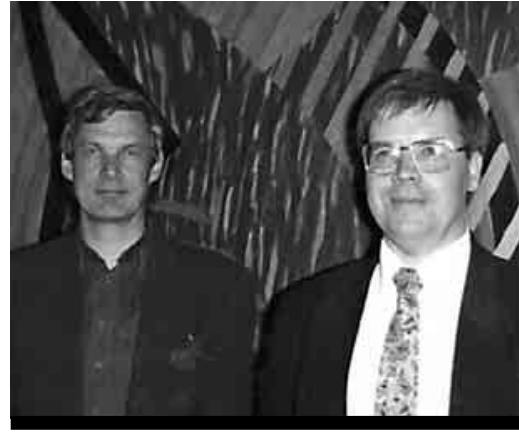

Figure 11

Markuu Koskenvuo (L) and Jaakko Kaprio.

indicated greater resemblance among the former, suggesting self-selection. However, the possibility of real assessment differences was also raised.

Subsequent studies assessed height and weight (Langinvainio, Koskenvuo, Kaprio, \& Sistonen, 1984), personality factors (Langinvainio, Kaprio, Koskenvuo, \& Lonnqvist, 1984) and smoking and drinking habits (Kaprio, Koskenvuo, \& Langinvainio, 1984).

\section{Research Samplings}

\section{Posttraumatic Stress: Predispositions}

Previous research has shown that people suffering from posttraumatic stress disorder (PTSD) have smaller hippocampal volumes (HV), relative to controls. A recent study of twin Vietnam war veterans has brought new clarity to this finding (Gilbertson, Shenton, Ciszwewski, Kasai, Lasko, Orr \& Pitman, 2002). The study used $40 \mathrm{MZ}$ twin pairs in a co-twin control design: one pair member had been exposed to combat, while the co-twin had not. Results confirmed the established relationship between stress exposure and reduced HV. However, it was also determined that both co-twins (whether exposed or unexposed to combat) showed reduced HV, relative to pairs in which neither twin experienced PTSD. Thus, lower HV appears to be present prior to stress, increasing vulnerability to its detrimental effects.

The investigators concluded that their data supported a genetic interpretation of individual differences in response to stress. An outside expert commenting on this study suggested that adverse prenatal factors "presumably shared by the twins", may be responsible for co-twins' similarly reduced HVs. However, prenatal factors are more likely linked to co-twin differences than similarities. A genetic explanation, thus, seems warranted.

\section{Synaesthesia: An Intriguing Case.}

Synaesthesia refers to situations in which common stimuli evoke unusual conscious experiences. Stimulus and response may be in the same modality, such as when seeing red or green produces color experiences. They may also occur in different modalities, such as when sounds or tastes trigger smell or touch experiences.

Canadian researchers have reported a remarkable case study of 11-year-old identical female twins discordant for synaesthesia (Smilek, Moffatt, Pasternak, White, Dixon \& Merikle, 2002).
A recent study compared resemblance for serum lipids and apolipoprotein E phenotypes in MZA and MZT twin pairs (Kervinen, Kaprio, Koskenvuo, Juntunen, \& Kesaniemi (1998). Correlations for low density protein (LDL) and for total cholesterol were approximately twice as high in MZT twins $\left(r_{i}=.50\right)$ than MZA twins $\left(r_{i}=.21\right)$, suggesting shared environmental effects. The same effect was found for total cholesterol (MZT: $r_{i}=.47$; MZA: $\left.r_{i}=.26\right)$. The two twin groups did not differ in high density lipoprotein (HDL) similarity. Finnish MZA twins were also represented in the international BMI twin study referenced above; the BMI correlation for the 17 pairs was .63 .

The majority of papers on Finnish twins have concerned reared together pairs. They have been numerous, spanning many behavioral and health domains. The International Twin Congress held in Helsinki in 1998 was memorable.
The monozygosity of the twins was confirmed by DNA profiling. One twin described color experiences upon hearing digits 1 through 9, with specific number-color associations that remained stable. Her co-twin did not report such events. In order to further compare the twins on these dimensions, they were administered a version of the Stroop test. The Stroop Test, described in 1935 by J.R. Stroop, measures individuals' degree of interference in task performance. The original test presented the names of colors printed in colored ink that that did not match the printed word (e.g., the word red might be printed in green ink). Various tasks involve naming the color of the ink versus saying the color word (e.g., color naming vs. word reading). The effects of practice on this task were also of interest (Stroop, 1935).

The twins were shown colored digits on a screen and asked to name the color as quickly as possible. The color of the digits was decided by the synaesthetic twin's previous 
color associations. Trials included both congruent and incongruent presentations. It was reasoned that the synaesthetic twin should have difficulty naming colors of digits in incongruent presentations, taking longer to do so than for congruent presentations. However, her non-synaesthetic twin sister was expected to show equal reaction times across congruent and incongruent presentations. Data analysis showed that the synaesthetic twin responded significantly faster across congruent than incongruent trials, as expected. In contrast, her co-twin's time did not differ across the two conditions. Error rates across conditions did not differ for either twin, showing that reaction times do "not appear to be compromised by speed/accuracy tradeoffs" (p. 340).

Several explanations for MZ female twin discordance for synaesthesia were offered. Differential X chromosome inactivation was one possibility - a previous study suggested that synaesthesia may be an X-linked dominant trait, so it may be that one twin had a higher proportion of relevant genes active than the other. Alternatively, possible mutation occurring in one twin could conceivably explain their observed difference in color experience. This interesting case will, hopefully, encourage further twin studies of this intriguing phenotype.

\section{Vanishing Twins: Biological and Experiential Events}

A sensitive and informed view of the vanishing twin syndrome was recently presented by a nurse practitioner, a professional uniquely positioned to follow events with an expectant mother of twins (Davis, 2002). A multiple conception was diagnosed by sonogram at 11 weeks into the pregnancy, and the news was joyful and exciting. The twins appeared to be fraternal. The mother was 39 years of age at the time and aware of the risks associated with twin gestations. The pregnancy was progressing well at the 13 th week examination.

Unfortunately, complications occurred two weeks later during the next follow-up - only one fetal heartbeat was detected. The nurse tried desperately to locate the second one, but was unable to do so. The mother correctly sensed that something was wrong and wept when she was finally informed that the second twin had vanished. The missing fetus was subsequently referred to as the "conceptus" or "demise".

The pregnancy progressed, culminating in the birth of a healthy female infant at 38 weeks. There were no physical indications that the pregnancy had begun as two - the mother's body had resorbed the second co-twin. However, the one physical reminder left behind was the living twin child. Little is known about parents' reactions to losing a twin in this way and, in fact, it is likely that many such losses escape detection. There is also an absence of information on the experience of the surviving twin. We know from previous work that loss of a cotwin at delivery can be a significant life event, leaving survivors saddened and unfulfilled (Woodward, 1997; Segal, 2000). Issues of diagnosis, frequency and complications from the vanishing twin syndrome have been addressed in the medical literature (Landy \& Keith, 1998), but its emotional aftermath has been overlooked.

Variability among samples, sonographic techniques and diagnostic criteria explain the wide range in the frequency $(3.7-100 \%)$ with which the vanishing twin syndrome is estimated to occur (Landy \& Keith, 1998). A more informative approach may be to organize twin gestations by type and time. Benson, Doubilet \& Laks (1993) found disappearance rates of $21 \%$ for dichorionic twins and 50\% for monochorionic twins, occurring between 6 and 7.9 weeks gestation. In contrast, disappearance did not occur in either group when assessed between 8 and 13 weeks. Most researchers have shown that vanishing twin rates are more likely to occur earlier than later in the first trimester.

\section{Great Debates: Conjoined Twinning and Twin Transplants}

A fascinating new volume, Ethics and Law in Modern Medicine (2002), edited by attorney David M. Vukadinovich and law professor Susan L. Krinsky, is available. Scanning the table of contents, chapter 8, Twins and Transplants: Choosing Who Lives, caught my eye. I believe it will interest readers of Twin Research.

The two cases presented here (conjoined twins and twins needing transplants) are hypothetical, as are all cases in the book. They are designed to stimulate dialogue over the ethical and legal issues raised by the pairs, in this case choosing who might be allowed to live, who might be sacrificed, and why. Discussion questions accompany each case and roles of parents, physicians, judges and advocates are assigned.

The first case involves conjoined female twins, both predicted to die by age 3 with $60 \%$ certainty in the absence of surgical separation. It is also estimated that sacrifice of one twin would allow the other a $75 \%$ chance, or better, of a normal life. There are no clear medical reasons for choosing one or the other; however, we later learn that Twin A is deaf and Twin B has a disfiguring facial birthmark. Should Twin A be allowed to live, she would receive a cochlea transplant from her twin; should Twin B be allowed to live, she would receive a skin graft from her twin. This case raises many significant and complex questions. I wonder, however, how realistic this case truly is - most conjoined twins, even those of the symmetric variety, do not show equal promise of survival. Thus, while I support the presentation of hypothetical cases, I believe they should mirror reality as closely as possible.

The second case involves the birth of identical twin boys, one of whom has hypoplastic left heart syndrome (Twin A), giving him a life expectancy of two weeks. His co-twin has anencephaly (Twin B), giving him a life expectancy of three days. Should Twin B's heart be transplanted into Twin A? If these infants were not twins, would this affect outcomes and opinions concerning this case? These complex questions are not easily answered, but the last question is especially intriguing, and could conceivably affect decision-making processes. Hastening the loss of one infant to preserve the life of another, no doubt, poses different personal, as well as medical, legal and ethical dilemmas when the children are from the same family versus different families.

I am pleased that cases concerning twins are included in a volume of interest to legal professionals outside the psychology and science of multiple birth. I would urge interested twin researchers to publish their own real life cases in collaboration with attorneys 
and bioethicists. Interdisciplinary efforts would insure that the widest range of issues and problems receives the greatest care and consideration.

Note: A recent paper describes successful kidney transplants involving two MZ female twin sets, one age
27 and the other age 61. The authors remind us of the significance of the first successful kidney transplant in an MZ twin, reported by Joseph E. Murray, in 1954: "The success of this procedure confirmed the importance of the immunologic basis of rejection and led to an interdisciplinary development in transplantation medicine" (p. 2205). In conclusion, they state that "the 'historical case' still occurs today" (p. 2206)

\section{Writers, Politicos, Artistry and Athleticism}

\section{Literature: Identical Twin Novelists with Non-identical Topics}

Identical twins, Robert and Richard Bausch, are both novelists, with books released in October, 2002. Both twins are also college professors, Robert at North Virginia Community College and Richard at George Mason Uniersity. Despite their similar careers, the subjects of their books differ substantially. Robert's book, The Gypsy Man, is based on a legend about a phantom that steals children. Richard's book, Hello to the Cannibals, concerns a modern woman's investigation of the traveler Mary Kingsley. Perhaps in an attempt to avoid competition or "borrowed ideas", the twins do not read each other's work prior to publication. Pursuing different projects within the same field may be a way for them to preserve their individuality and their twinship.

\section{Politicos and Professors: The Southern Twins}

They are the "Poli-Sci Gemini" (Jubera, 2002). Identical twins, Merle and Earl Black, are leading experts on political events in the southern United States. Both hold university chairs in political science, Merle at Emory University in Atlanta, Georgia and Earl at Rice University in Houston, Texas. They are co-authors of The Rise of Southern Republicans (2002), The Vital South: How Presidents Are Elected (1992) and Politics and Society in the South (1987), all published by Harvard University Press. Their scholarship is regarded as exemplary by their colleagues. Hastings Wyman, publisher of the Southern Political Report, said in Jubera's piece that, "Others have written well, but they've written more, and written more comprehensively".

The Black twins, now 60, were raised in Sulphur Springs, Texas. Their fascination with southern politics came early, and persisted except for one day when Merle declared himself an English major. Their educational careers show parallels and divergences: Merle received his BA from Harvard and his $\mathrm{PhD}$ from the University of Chicago; Earl received his BA from the University of Texas and his $\mathrm{PhD}$ from Harvard. They are great friends and true collaborators, bringing compatible, but complementary styles to their work. Merle prefers to keep researching subjects, but is kept in check by Earl who knows when to stop. (I imagine that many more academic papers and projects would come to completion if their authors had identical co-twins like Earl!) The twins' common interests and preferences are not confined to their scholarship. Both played football in high school, taking corresponding positions of right (Earl) and left tackle (Merle). For music it's Mahler, for openers it's oatmeal.

Looking at their publications, I was curious as to why Earl was always senior author and how this was decided. I sent both twins the same email message and received the first response from Merle. He explained that the twins have " ... contributed equally to the three books ... We think of ourselves as a team." It seems that Earl had previously published a singly-authored book, Southern Governors and Civil Rights: Racial Segregation as a Campaign Issue in the Second Reconstruction (1976), with the same press and same editor, so "once we were published that way, it made sense to keep it in that order. It makes no difference to me to be listed second". His words exemplify the camaraderie and collaboration for which MZ twins are famous. Underlining this point was Earl's later response which read, "Merle answered your questions perfectly".

\section{Photography: Enduring Images}

Not long ago I met a colleague in the department mailroom who told me about a striking photograph of twins, published in the latest New Yorker Magazine. "It's just amazing!" he said. "You have to see it!" I rushed out to purchase a copy, then took a look I had seen these twins before! A larger glossy photo of them is included in a wonderful compendium, Parallels: A Look at Twins, by Ted Wolner and Harvey Stein (1978). The picture shows 9-year-old Puerto Rican twins from Brooklyn, New York. The twins have albinism and this, together with their matching horn-rimmed glasses, wiry bodies and 70 s t-shirts make them a rare, memorable pair.

\section{Athletics}

The Bedser twins. I had not heard of Britain's Alec and Eric Bedser until I read a lengthy newspaper story extolling their legendary athleticism. Born on July 4, 1918, they are famous for their skills in cricket, a game they played since age 5 . They were raised in Woking, a rural town to which they have returned, now that they are in their $80 \mathrm{~s}$.

Alec is considered England's best bowling standard bearer after World War II. In 1997 he received a knighthood, the first ever given to a bowler. His twin brother, Eric, was also a superb player. Both twins were also highly honored in Australia, a nation they visited often.

The life histories of these remarkable twins are replayed in a recent book, The Bedsers: Twinning Triumphs, authored by journalist Alan Hill. 


\section{References}

Allison, D. B., Kaprio, J., Korleila, M., Koskenvuo, M., Neale, M. C., \& Hayakawa, K. (1996). The heritability of body mass index among an international sample of monozygotic twins reared apart. International Journal of Obesity and Related Metabolic Disorders, 20, 50I-506.

Benson, C. B., Doubilet, P. M., \& Laks, M. P. (1993). Outcomes of twin gestations following sonographic demonstration of two heart beats in the first trimester. Ultrasound Obstetrics and Gynecology, 3, 343-345.

Black, E. (1976). Southern governors and civil rights: Racial segregation as a campaign issue in the second reconstruction. Cambridge, MA: Harvard University Press.

Black, E., \& Black, M. (1987). Politics and society in the South. Cambridge, MA: Harvard University Press.

Black, E., \& Black, M. (1992). The vital south: How presidents are elected. Cambridge, MA: Harvard University Press.

Black, E., \& Black, M. (2002). The rise of southern Republicans. Cambridge, MA: Harvard University Press.

Boomsma, D. (1998). Twin registries in Europe: An overview. Twin Research, I, 34-5I.

Bouchard, T. J., Jr., Lykken, D. T., McGue, M., Segal, N. L., \& Tellegen, A. (1990). Sources of human psychological differences: The Minnesota Study of Twins Reared Apart. Science, 250, 223-228.

Bryan, E. (1992). Twins and multiple births. New York: Little, Brown \& Co.

Busjahn, A. (2002). Twin registers across the globe: What's out there in 2002? Twin Research, 5, v-vi. (Special issue on twin registries).

Davis, C. (2002). Vanishing twin syndrome. Discover Magazine, 23, 24-25.

Gilbertson, M. W., Shenton, M. E., Ciszwewski, A., Kasai, K., Lasko, N. B., Orr, S. P., et al. (2002). Smaller hippocampal volume predicts vulnerability to psychological trauma. Nature Neuroscience, October 15.

Gumprich, M., Woeste, G., Kohlhaw, K., Epplen, J. T., \& Bechstein, W. (2002). Living related kidney transplantation between identical twins. Transplantation Proceedings, 34, 2205-2206.

Hayakawa, K. (1987). Smoking and drinking discordance and health condition; Japanese identical twins reared apart and together. Acta Geneticae Medicae et Gemellologiae, 36, 493-50I.

Hayakawa, K., \& Shimizu, T. (1987). Blood pressure discordance and lifestyle: Japanese identical twins reared apart and together. Acta Geneticae Medicae et Gemellologiae, 36, 485-49I.

Hayakawa, K., Shimizu, T., Kato, K., Onoi, M., \& Kobayashi, Y. (2002). A gerontological cohort study of aged twins: The Osaka University Aged Twin Registry. Twin Research, 5, 387-388.

Hayakawa, K., \& Sogi, A. (2000). Concordance rates and intra-pair comparison of lymphocyte subjects in adult twins. Japanese Journal of Public Health, 48, 257.

Hill, A. (200I). The Bedsers: Twinning triumphs. Edinburgh: Mainstream Publishing.

Jubera, D. (8 April 2002). The poli-sci gemini. Atlanta Journal-Constitution.

Juel-Nielsen, N. (1965). Individual and environment: Monozygotic twins reared apart. New York: International Universities Press.

Kaprio, J., \& Koskenvuo, M. (2002). Genetic and environmental factors in complex diseases: The older Finnish twin cohort. Twin Research, 5, 358-365.

Kaprio, J., Koskenvuo, M., \& Langinvainio, $\mathrm{H}$. (1984). Finnish twins reared apart. IV: Smoking and drinking habits. A preliminary analysis of the effect of heredity and environment. Acta Geneticae Medicae et Gemellologiae, 33, 425-433.

Kaprio, J., Koskenvuo, M., \& Rose, R. J. (1990). Population-based twin registries: Illustrative applications in genetic epidemiology and behavioral genetics from the Finnish Twin Cohort Study. Acta Geneticae Medicae et Gemellologiae, 39, 427-439.

Landy, H. J., \& Keith, L. G. (1998). The vanishing twin: A review. Human Reproduction Update, 4, I77-183.

Langinvainio, H., Kaprio, J., Koskenvuo, M., \& Lonnqvist, J. (1984). Finnish twins reared apart. III: Personality factors. Acta Geneticae Medicae et Gemellologiae, 33, 259-264.

Langinvainio, H., Koskenvuo, M., Kaprio, J., \& Sistonen, P. (1984). Finnish twins reared apart. II: Validation of zygosity, environmental dissimilarity and weight and height. Acta Geneticae Medicae et Gemellologiae, 33, 25I-258.

Lichtenstein, P., De Faire, U. Floderus, B., Svartengren, M., Svedberg, P., \& Pedersen, N. L. (2002). The Swedish Twin Registry: A unique source for clinical, epidemiological and genetic studies. Journal of Internal Medicine, 252, I84-205.

Kendler, K. S., Thornton, L. M., \& Pedersen, N. L. (2000). Tobacco consumption in Swedish twins reared apart and together. Archives of General Psychiatry, $37,886-892$.

Kervinen, K., Kaprio, J., Koskenvuo, M., Juntunen, J., \& Kesaniemi, Y. A. (1998). Serum lipids and apolipoprotein E phenotypes in identical twins reared apart. Clinical Genetics, 53, 191-199.

McClearn, G. E., Johansson, B., Berg, S., Pedersen, N. L., Ahern, F., Petrill, S., \& Plomin, R. (1997). Substantial genetic influence on cognitive abilities in twins 80 or more years old. Science, 276 , 1560-1563.

Newman, H. N., Freeman, F. N., \& Holzinger, K. J. (1937). Twins: A study of heredity and environment. Chicago: University of Chicago Press.

Olaleye-Oruene, T. O. (2002). The Yoruba's cultural perspective of death with special reference to twins. Twin Research, 5, I54-155.

Pedersen, N. L., Lichtenstein, P., \& Svdeberg, P. (2002). The Swedish Twin Registry in the third millenium. Twin Research, 5, 427-432.

Pedersen, N. L., McClearn, G. E., Plomin, R., \& Friberg, L. (1985). Separated fraternal twins: Resemblance for cognitive abilities. Behavior Genetics, 15, 407-4I9.

Plomin, R., Pedersen, N. L., Lichtenstein, P., \& McClearn, G. R. (1994). Variability and stability in cognitive abilities are largely genetic later in life. Behavior Genetics, 24, 207-215.

Segal, N. L. (2000). Entwined lives: Twins and what they tell us about human behavior. New York: Plume.

Segal, N. L., \& Russell, J. (199I). IQ similarity in monozygotic and dizygotic twin children: Effects of the same versus separate examiners: A research note. Journal of Child Psychology and Psychiatry, $32,703-708$

Shields, J. (1962). Monozygotic twins: Brought up apart and together. London: Oxford University Press.

Slater, E., \& Shields, J. (I953). Psychotic and neurotic illnesses in twins. Medical Research Council Special Report, 278. London: Medical Research Council.

Smilek, D., Moffatt, B. A., Pasternak, J., White, B. N., Dixon, M. J., \& Merikle, P. M. (2002). Synaesthesia: A case study of discordant monozygotic twins. Neurocase, $8,338-342$.

Sorensen, T. I. A. (2002). Contributions and potentials of Swedish twin research. Journal of Internal Medicine, 252, $|8|-\mid 83$.

Stewart, E. A. (2000). Exploring twins: Towards a social analysis of twinship. London: MacMillan Press Ltd.

Stroop, J. R. (1935). Studies of interference in serial verbal reactions. Journal of Experimental Psychology, 18, 643-662.

Tellegen, A., Lykken, D. T., Bouchard, T. J., Jr., Wilcox, K. J., Segal, N. L., \& Rich, S. (1988) Personality similarity in twins reared apart and together. Journal 
of Personality and Social Psychology, 54, 1031-1039.

University of Chicago Exhibition Catalogues (16 January 2002). The university and the city: A centennial view of the University of Chicago, http://www.lib.uchicago.edu/e/ spcl/excat/city2.htm
Veith, I. (1960). Twin birth: A Japanese view. International Journal of Social Psychology, 6, 230-236.

Vukadinovich, D. M. (2002). Twins and transplants. In D. M. Vukadinovich \& S. L. Krinsky (Eds.), Ethics and law in modern medicine: Hypothetical case studies. Dordrecht, the Netherlands: Kluwer.

Wolner, T, \& Stein, H. (1978). Parallels: A look at twins. New York: E.P. Dutton.

Woodward, J. (1997). The lone twin. London: Free Association Books. 